\title{
METHODOLOGY OF APPLICATION OF MODERN TECHNOLOGIES IN LAND INVENTORY OF TERRITORIAL COMMUNITIES
}

\author{
Koshkalda Iryna ${ }^{1}$, Anopriienko Tetiana ${ }^{1}$, Pilicheva Maryna², Maslii Lubov² \\ ${ }^{1}$ Kharkiv National Agrarian University named after V.V. Dokuchayev, \\ ${ }^{2}$ O. M. Beketov National University of Urban Economy in Kharkiv
}

\begin{abstract}
The article defines that the land inventory allows to form land plots of state and communal property, to fill the State Land Cadastre with information about objects and subjects of land relations and to eliminate existing errors. The aim of the article is to improve the procedure of conducting the land inventory in Ukraine, taking into account modern technologies within the current regulatory framework. The methodology of land inventory using modern technologies has been developed, which includes the following components: surveying of the inventory object, topographic and geodetic works, vectorization of its territory using remote sensing data, project works, creation of a consolidated inventory plan, development of technical documentation, its state expertise, adjustment and approval, entering data into the State Land Cadastre. It is established that an effective method of implementation of topographic and geodetic works during updating of the cartographic materials is a combined method, which includes the use of aerial images with simultaneous geodetic surveying of complex areas. The use of geoinformation technologies and remote sensing data is allowed to optimize the duration and frequency of land inventory. In particular, the classification of land should be performed in the attribute tables. Ways to solve problems of protection and rational use of the lands of the inventory object have been developed. They include registration of land plots without cadastral numbers; control of compliance of land and environmental legislation, taking into account the results of land inventory for updating statistical cadastral information and making changes of the State Land Cadastre data.
\end{abstract}

Key words: land use, land inventory, territorial communities, GIS technology, remote sensing data

\section{Introduction}

The revelation and functioning of the land market, especially agricultural land, requires its regulation by the state - accounting for quantity and quality, protection of land and their rational use. Therefore, one of the important measures is to fill the geographic information system of the State Land Cadastre with reliable and complete information about the objects and subjects of land relations and to eliminate existing errors as a result of a continuous land inventory. At the same time, the location of land plots, their boundaries, sizes, legal status and restrictions are established, lands that are not used, used irrationally or not for their intended purpose are identified, and their qualitative characteristics are established.

According to the decentralization of power in Ukraine, the creation and future increase of territorial community areas through their unification, land inventory becomes one of the key factors of their further success and development, planning and receipt of funds to the local budget from land tax and land rent depends on condition and amount of land the community will receive. It is possible to form land plots of state and communal property on the basis of land inventory materials.

The vast majority of countries in the world have 4 stages of lands inventory: determining current land use conditions, preparing a base map, deciding on land use categories collecting current land use data, preparing the current land use map (Land Use..., 2005). Computerized Land Information Systems (LIS), based on GIS, are widely used at all stages to manage and analyze a large number of data on the use of land resources, perform statistical and spatial processing, create the necessary information products in the form of maps, as well as tabular and textual reports for the management decision-making (Sombroek W.G.; Antoine J., 2000; Udovenko et.al., 2020). Typical methods for the determination of the current state of land use are modern technologies, such as: terrestrial geodetic survey methods for urban development, aerial photography and space survey data for rural areas and country estates (Land Use..., 2005; Lowry, 2006; Ramteke et. al., 2018).

Problems of improving the State Land Cadastre and land inventory in Ukraine have been studied in the works of domestic scientists (Кондратенко, 2019; Дорош, 2015; Лакатош, 2013; (Мартин, 2012; Нестеренко, Бідун 2013; Bavrovska, Boryskevych, 2017), where researchers note that the information function of the inventory is one of the main, as it ensures the reliability of information on land. The inventory results later become the basis for making many management decisions, and most importantly - financial decisions. 
Despite the above, today there is no unambiguous view on the essence of land inventory as a form of obtaining (updating, adjusting) information on the state of land tenure and land use, which is entered in the State Land Cadastre of Ukraine.

\section{Methodology of research and materials}

Therefore, the aim of the article is to improve the procedure of conducting the land inventory in Ukraine, taking into account modern technologies within the current regulatory framework.

The following tasks were set for achieving this goal:

1. to analyze the existing regulatory framework of land inventory in Ukraine;

2. to study the technological process of land inventory in Ukraine;

3. to form a methodology for conducting land inventory works using modern technologies on the example of the territorial community;

4. to develop recommendations for the rational use of the land inventory object.

The object of study is the land resources of the territorial community.

The article uses methods of analysis, synthesis and generalization of regulations, scientific literature, land management documentation for land inventory and statistics.

\section{Discussions and results}

In Ukraine works on land inventory are carried out according to the "Procedure for conducting land inventory and recognizing some resolutions of the Cabinet of Ministers of Ukraine as invalid " (Про затвердження Порядку ..., 2019).

To conduct the land inventory of the territorial community, the customer (local government) enters into an agreement with the contractor to develop technical documentation, which reflects the cost and timing of work, which should not exceed six months since the signing a contract.

The contract is also accompanied by an estimated budget and terms of reference for land inventory work, which is issued by the customer, approved by the contractor and includes: basis for work, purpose of work, brief description of the object, initial data for work, requirements for technical documentation, expected results and the order of works realization, materials which are provided after the termination of works, the order of delivery of the developed technical documentation.

The general procedure for conducting a community land inventory is shown in Figure 1 and it consists of 4 main stages (Про затвердження Порядку ..., 2019): survey stage, topographic and geodetic stage, design, seach and approval stage and approval of technical documentation on land management for land inventory. Geographic information technologies are used for fast and high-quality source data processing, as well as inventory of objects. The advantage of using GIS is that the creation of graphic materials significantly increases the accuracy of drawings, in addition, electronic cartographic materials can be used an unlimited number of times to reproduce both the general drawing and fragments, to overlap some drawings on others.

The first stage of the land inventory procedure is survey work, which includes collection and analysis of initial data for land inventory (materials from the State Fund of Land Management Documentation, planning and cartographic materials, etc.) and field survey of the inventory object by the executor. The results of the work performed are presented on a working inventory plan, which is based on the next cadastral plan or other planning and cartographic materials within cities and towns - at a scale of not less than 1: 5000, within rural settlements - at a scale of not less than 1: 2000, within the territories defined as formation of the territory and establishment of village borders, settlement councils by the projects - in scale not less than 1: 10000, within districts - in scale 1:25000, with indication of borders: object of inventory; administrative-territorial units that are part of the object of inventory; territories defined by projects of territory formation and establishment of city, settlement, village councils borders; lands of all forms of ownership; land plots included in the State Land Cadastre; restrictions (encumbrances) in the use of land. 


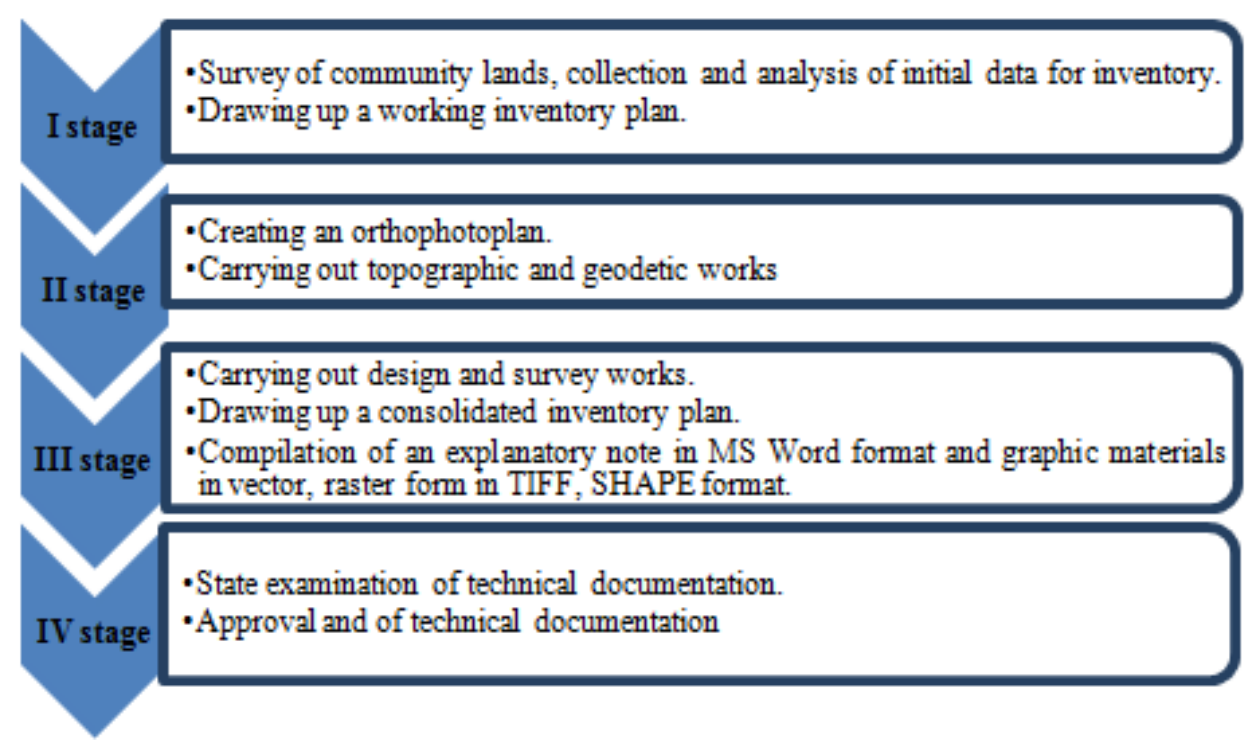

Fig. 1. Stages of land inventory

Based on modern experience of topographic and geodetic works, the most effective method of updating the cartographic basis is a combined method, which includes the use of aerial photography materials with simultaneous instrumental geodetic survey of the most complex areas that require a more detailed image.

The technological process of creating an orthophoto is shown in Figure 2, which schematically shows the transformation of individual images into a single orthophoto.
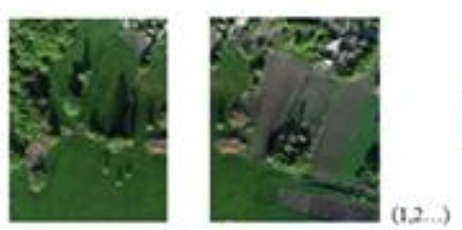

Route pictures

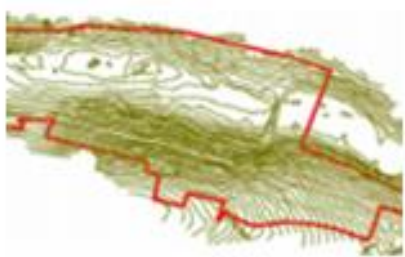

Digital district model

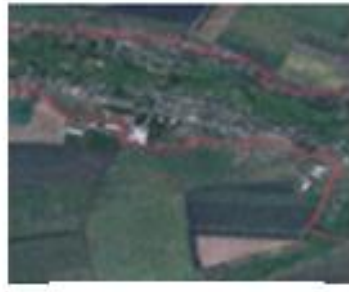

Orthophotoplan

Fig. 2. Technological process of creating an orthophotoplan

A detailed list of works while creating an orthophotoplan is shown in Figure 3.

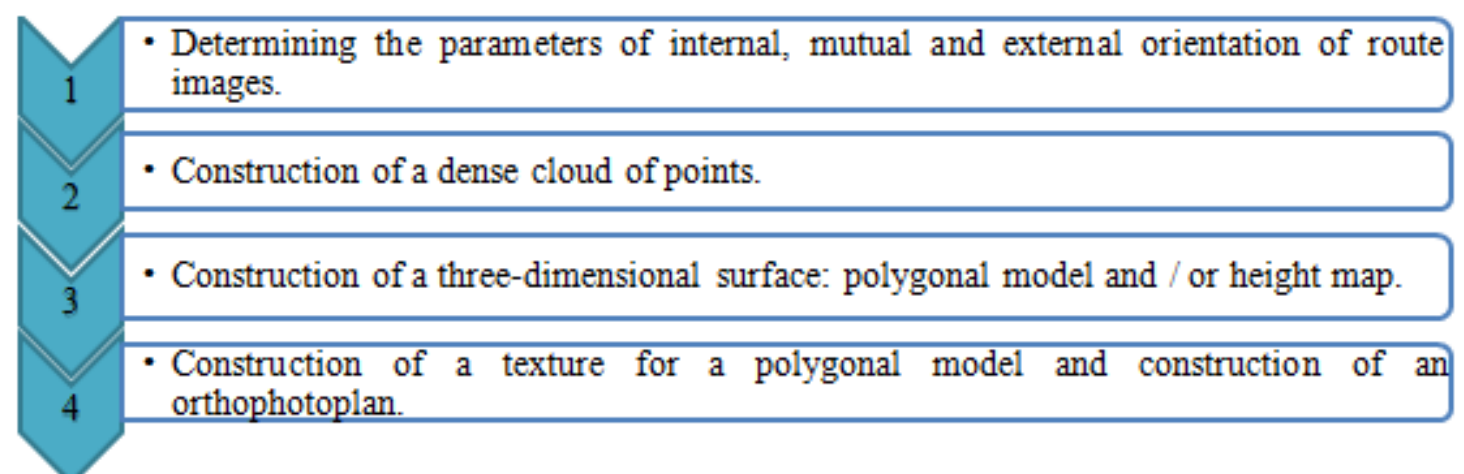

Fig. 3. Stages of creating an orthophotoplan

At the first stage of an orthophotoplan creation common points of pictures are found and elements of mutual orientation of pictures of a route are defined by these points. The result of the stage is a sparse cloud of common points in the 3D space of the model and data on the orientation of the camera, which 
serves only to visually assess the quality of image alignment. In the second stage, a dense cloud of points is constructed based on the camera positions and images at the time of taking photos. The third stage is a three-dimensional polygonal model that describes the shape of an object based on a dense cloud of points. Sometimes it is possible to proceed the construction of a height map, refusing the construction of a polygonal model. The choice of cartographic projection is obligatory. At the final stage, the orthophotoplan is projected on the surface specified by the user, it can be a height map or a polygonal model.

In order to link aerial photography materials to the area, as well as to determine or clarify the boundaries of land plots, restrictions (encumbrances) in their use and lands, field geodetic works are performed in order to obtain the coordinates of the survey base points. The starting points of the state geodetic network are the nearest permanent stations. The points of the shooting base are temporarily fixed on the ground with cross-shaped marks, which are located on the scheme of the plan basis (Fig. 4).

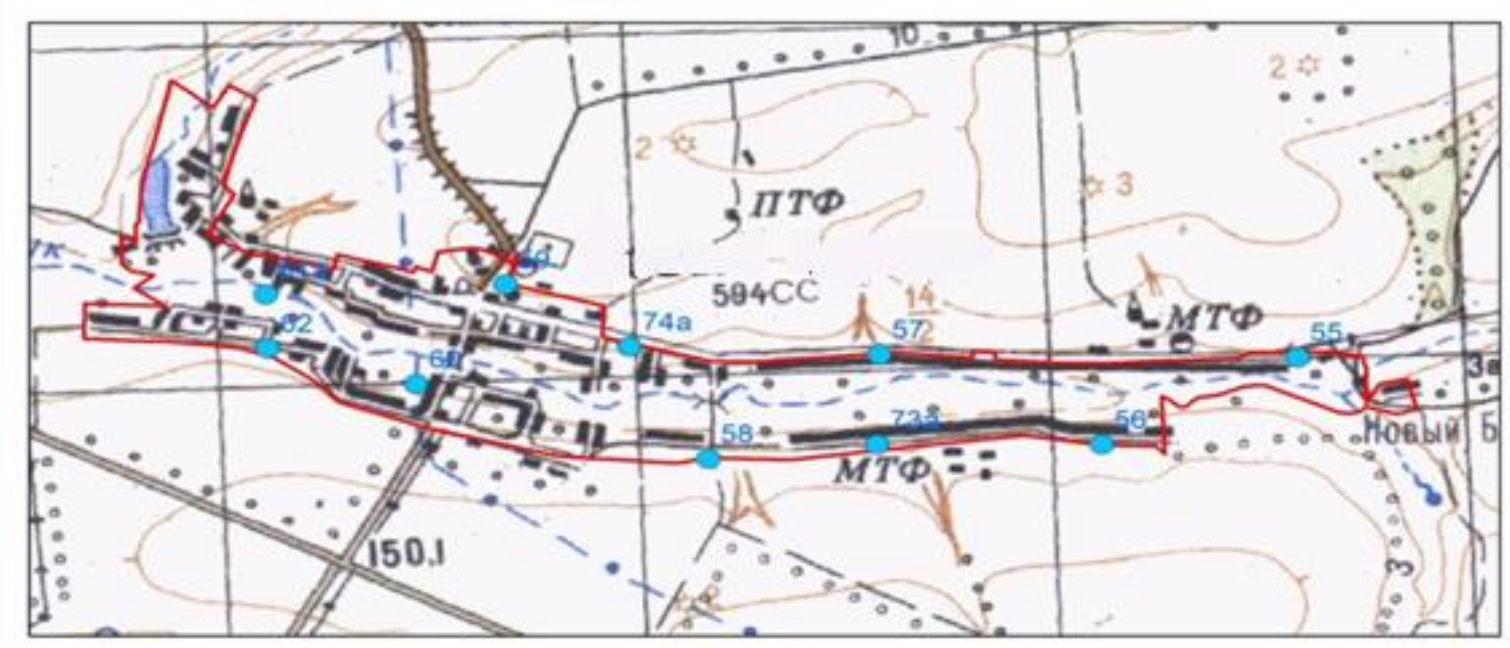

Fig. 4. Scheme of the plan basis with points of geodetic network

The coordinates of the shooting base points are determined by satellite methods using GPS receivers. Observations were performed only by static method, by separate sessions. The duration of the sessions while determining the points of the shooting base is minimum 20 minutes. The recommended number of observed satellites is minimum four, during the study their number averaged 8-9. The measurement results are shown in Table 1.

Table 1

Data of route mean square deviations (RMS) of the planned basis

\begin{tabular}{|c|c|c|c|c|}
\hline Point & RMS by X, m & RMS by Y, m & RMS by H, m & RMS by XY, m \\
\hline $61 \mathrm{a}$ & 0.012 & 0.012 & 0.015 & 0.013 \\
\hline 62 & 0.011 & 0.012 & 0.014 & 0.012 \\
\hline 59 & 0.010 & 0.009 & 0.019 & 0.014 \\
\hline $74 \mathrm{a}$ & 0.010 & 0.009 & 0.018 & 0.014 \\
\hline 57 & 0.010 & 0.009 & 0.019 & 0.014 \\
\hline 55 & 0.010 & 0.009 & 0.018 & 0.014 \\
\hline 56 & 0.011 & 0.012 & 0.018 & 0.013 \\
\hline $73 \mathrm{a}$ & 0.010 & 0.009 & 0.014 & 0.014 \\
\hline 58 & 0.010 & 0.009 & 0.020 & 0.014 \\
\hline 60 & 0.010 & 0.012 & 0.019 & 0.014 \\
\hline
\end{tabular}

Survey of complex areas is performed tacheometrically using tacheometers or satellite methods. Survey of the homestead's boundaries, industrial and socio-cultural facilities and engineering networks was performed by satellite using GPS receivers. Satellite observations were performed from the base station in Stop and Go mode and in RTK mode, with separate sessions at each static point for at least 5 minutes, the number of satellites observed is minimum 7 . Kinematic measurements were performed at an average speed of $6 \mathrm{~km} /$ year with a data resolution of $2 \mathrm{~s}$. During the topographic and geodetic works, land plots were also inspected for the presence and / or absence of power grids with a voltage of $0.4 \mathrm{kV}$ and more, main pipelines and other objects with special creation and protection conditions were also inspected. 
To ensure the reflection required accuracy for the account area accepted unit of the deviation of land plot boundaries turning points relative to the nearest points of the state geodetic network should not exceed (Про затвердження Порядку ..., 2019):

- in cities Kyiv, Sevastopol and cities of regional subordination - 0.1 meters;

- in other cities and towns -0.2 meters;

- in villages -0.3 meters;

- outside the settlements -0.5 meters.

During the land inventory, the area of the land plot is indicated up to 1 sq. meter, taking into account the deviation of the plan scale in the case when the coordinates of the boundary turning point are determined with an accuracy of 0.01 meters.

Then design and survey works are carried out in order to process the data of topographic and geodetic works, create a geodatabase and perform vectorization of objects in the inventory area. All lands are subject to classification by purpose, availability of title documents for land, form of ownership, others and by entering the necessary information in the attribution tables in the process of vectorization, which allows to optimize the work when performing land inventory. The result of land inventory is a consolidated inventory plan (Fig. 5).
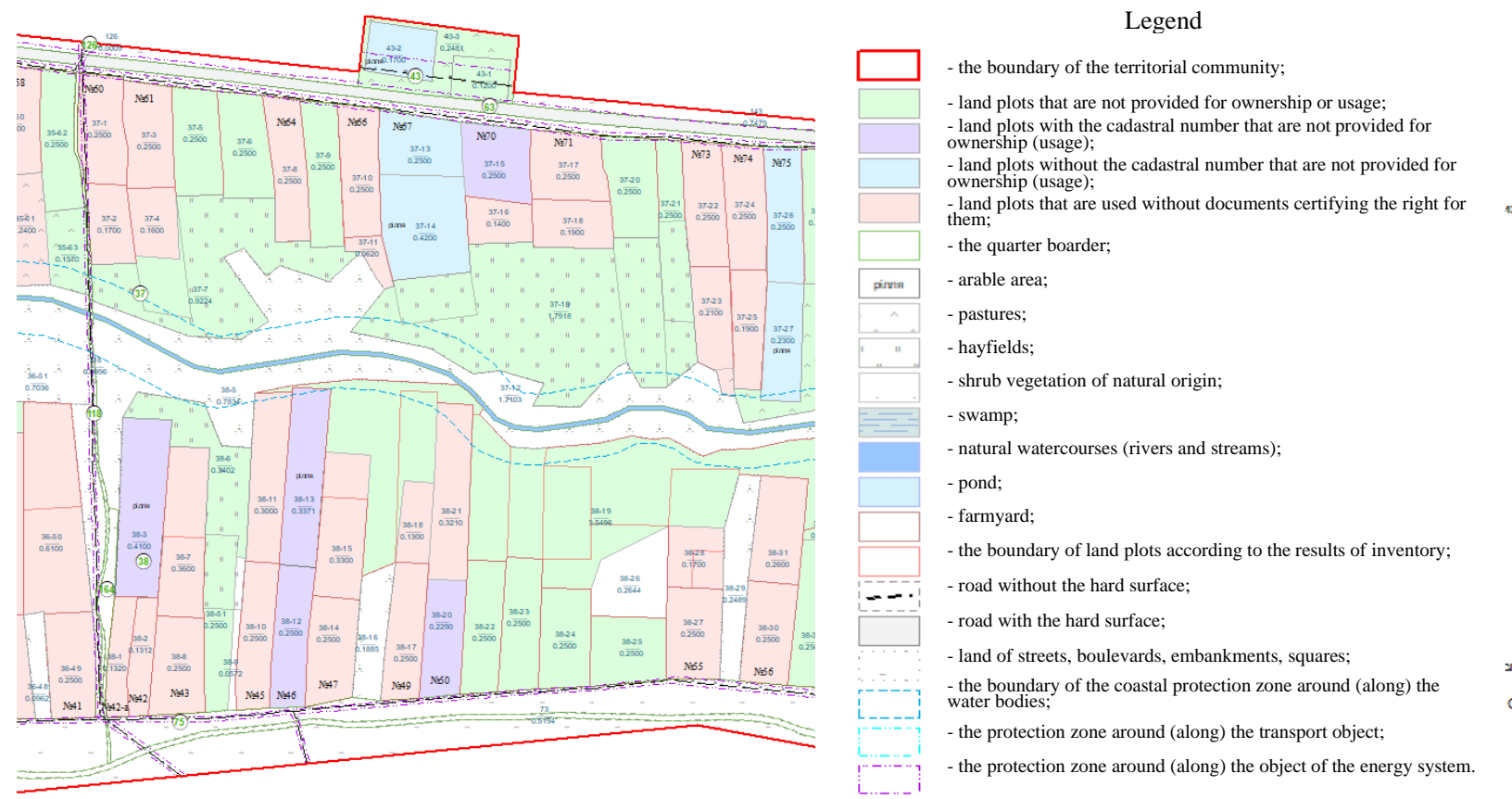

Fig. 5. Fragment of a consolidated inventory plan

The consolidated inventory plan draws the boundaries of (Про затвердження Порядку ..., 2019):

- land plots provided for ownership (usage);

- land plots not provided for ownership (usage);

- land plots used without documents certifying the right to them, or not for the intended purpose;

- existing restrictions in the use of land;

- unclaimed land shares ("pais"/land units);

- land plots (lands) of deseased heritage;

- lands;

- water bodies and hydraulic structures;

- irrigated and drained lands.

Appropriate summary tables are created. An example of a consolidated comparative table of data obtained as a result of land inventory and according is given in Table 2 . 
Table 2

Consolidated comparative table of data obtained as a result of land inventory and accounting

\begin{tabular}{|c|l|c|c|c|}
\hline No. & \multicolumn{1}{|c|}{ Land title } & $\begin{array}{c}\text { Area according } \\
\text { to land } \\
\text { accounting } \\
\text { reports, ha }\end{array}$ & $\begin{array}{c}\text { Area according to } \\
\text { the data obtained } \\
\text { as a result of land } \\
\text { inventory, ha }\end{array}$ & Variance, ha \\
\hline 1 & Arable & 89.5468 & 55.6602 & -33.8866 \\
\hline 2 & Perennial plantings & 31.9000 & - & -31.9000 \\
\hline 3 & Hayfields & 72.4000 & 109.2611 & 36.8611 \\
\hline 4 & Pastures & 38.3000 & 38.9664 & 0.6664 \\
\hline 5 & $\begin{array}{l}\text { Land under agricultural and other farm } \\
\text { buildings and yards }\end{array}$ & 12.5430 & 14.7912 & 2.2482 \\
\hline 6 & Other forest plantings & 1.8765 & 0.4530 & -1.4235 \\
\hline 7 & Shrub vegetation of natural origin & 30.0986 & 27.8946 & -2.2040 \\
\hline 8 & Land for housing & 57.1342 & 84.9875 & 27.8533 \\
\hline 9 & Lands under socio-cultural facilities & 1.7309 & 3.5183 & 1.7874 \\
\hline 10 & Land under buildings and structures of & 0.0123 & 0.0100 & -0.0023 \\
\hline
\end{tabular}

The fourth stage is the creation of an electronic document containing information on the results of land management and land valuation in electronic form in XML format (in the case of state or communal land formation), approval of the developed technical documentation and its state examination. Together with the positive conclusion of the state examination, the technical documentation is submitted for approval, followed by tansmission in paper and electronic forms to the territorial body of the State Geocadastre for entering data into the State Land Cadastre.

On the basis of the received data of land inventory the decisions of land protection and rational land use of inventory object are developed, the recommendations concerning the following can be the examples: 1. Registration of land plots without cadastral numbers in the State Land Cadastre by owners / users of land plots, in order to prevent the imposition of land plots on adjacent land plots when registering the ownership of new land plots.

2. Carrying out explanatory works with land users who use land plots without documents certifying the right to them, regarding their registration of the right to land plots according to the current legislation of Ukraine.

3. Monitoring compliance of land and environmental legislation, land use and protection by local governments and state administrations.

4. Using the results of land inventory when updating statistical cadastral information and making changes to the State Land Cadastre by the departments of the State Geocadastre.

5. Taking into account the results of land inventory when making decisions related to land issues and changes in the legal status of land by local governments.

\section{Conclusions and proposals}

Summarizing all the issues, we can say that:

1. In order to update the data on the land community fund, it is advisable to conduct a land inventory every 3-5 years.

2. In order to improve the procedure for conducting land inventory, local governments and executive authorities need to take urgent measures for the organized implementation of works and ensuring their proper funding.

3. In order to simplify the procedure for conducting land inventories, it is necessary to update the cartographic basis, as well as to develop general plans and projects for the establishment and restoration of settlements and territorial communities' boundaries.

4. Issue is to update the data on the accounting forms for the number of lands based on the results of the inventory and update the Land Books, most of which do not meet current requirements. New forms of statistical reporting should include information that is missing or partially not collected in the State Land Cadastre system. Codes of economic activities and statistical codes of economic entities organizational forms are completely absent, which leads to obtaining them from other sources and conducting significant research. Today it is necessary to make changes to the information base of the electronic document in XML format in terms of inputting this information. 
5. In order to increase the accuracy of the land inventory, there is a need to inform the public about it. After all, one of the problems of inventory is the lack and insufficiency of information on title documents for land plots.

The given methodology of modern technologies application at inventory of territorial communities' lands will allow to reduce financial, time and resource expenses for carrying out and realization of the further data actualization on resource potential of communities.

\section{References}

1. Bavrovska N., Boryskevych O. (2017) Inventory of land as the forming tool for the state land cadastre of ukraine in modern conditions. Viewed 21 January, 2021, (https://llufb.llu.lv/Raksti/Journal_Baltic_Surveying/2017/Journal_Baltic_SurveyingVol6_2017-51-58.pdf).

2. Land Use. Resource guide (2005) revised by Center for Land Use Education, University of WisconsinStevens Point/Extension. 136 p.

3. Lowry J. (2006). Low-cost GIS software and data for wetland inventory, assessment and monitoring. Gland, Switzerland. 32 p.

4. Ramteke I.K., Sen T. K., Singh S. K., Chaterjee S., Obi Reddy G.P., Rajankar P. B., Das S.N. (2018). Geospatial techniques in land resource inventory and management: a review. International Journal of Remote Sensing \& Geoscience (IJRSG), Volume 7, Issue 1, pp. 8-19.

5. Sombroek W.G., Antoine J. (2000). The Use of Geographic Information Systems (GIS) in Land Resources Appraisal. Viewed 21 January, 2021, (https://horizon.documentation.ird.fr/exldoc/pleins_textes/pleins_textes_6/colloques2/010008433.pdf).

6. Udovenko I., Kyselov I., Shemyakin M., Domashenko H., Kononenko S. (2020) Land inventory on the basis of methods of GIS technologies use. Viewed 21 January, 2021, (http://lib.udau.edu.ua/bitstream/123456789/7545/1/Udovenko\%2C\%20I.\%2C\%20Reznik\%2C\%20N.\%2C $\% 20 \mathrm{Kyselov} \% 2 \mathrm{C} \% 20 \mathrm{I} . \% 2 \mathrm{C} \% 20$ Shemyakin $\% 2 \mathrm{C} \% 20 \mathrm{M} . \% 2 \mathrm{C} \% 20 \mathrm{Domashenko} \% 2 \mathrm{C} \% 20 \mathrm{H} . \% 2 \mathrm{C} \% 20 \mathrm{Kono}$ nenko\%2C\%20S.\%20Land\%20inventory\%20based\%20methods\%20of\%20gis\%20technologies\%20use.pd f).

7. Дорош О. С. (2015) Інвентаризація земель: методичні підходи до їі проведення [Land inventory: methodological approaches to its implementation]. АгроСвіт, №. 11, с. 24-30. (in Ukrainian)

8. Кондратенко Д. Ю. (2019) Інвентаризація земель як правова форма обліку земель [Land inventory as a legal form of land registry]. Науковий вісник Міжнародного гуманітарного університету. Сер.: Юриспруденція, № 42, Том. 1, с. 124-128. (in Ukrainian)

9. Лакатош М. І. (2013) Необхідність проведення інвентаризації земель в Україні. Організаційно-правові передумови [The need for land inventory in Ukraine. Organizational and legal prerequisites]. Науковий вісник Ужгородського університету. Серія «Географія. Землеустрій. Природокористування», № 2, pp. 156-161. (in Ukrainian)

10. Мартин А. Г. (2012). Інвентаризація земель: як ії̈ здійснювати в сучасних умовах [Land inventory: how to carry it out in modern conditions]. Viewed 20 January, 2021, (http://www.zsu.org.ua/index.php?option=com content \&view=article\&id=2254:2011-05-27-14-4838\&catid=62:2011-01-12-14-57-08\&Itemid=87 ). (in Ukrainian)

11. Нестеренко Г. А., Бідун І. В. (2013). Інвентаризація земель як основний компонент у земельному кадастрі та системі управління земельними ресурсами (на прикладі Ківерцівського району Волинської області) [Land inventory as the main component in the land cadastre and land resources management system (on the example of Kivertsy district of Volyn region)]. Вісник Львівського національного аграрного університету. Серія «Економіка АПК», № 20(2), с. 153-158. (in Ukrainian)

12. Про затвердження Порядку проведення інвентаризації земель та визнання такими, що втратили чинність, деяких постанов Кабінету Міністрів України (Procedure for conducting land inventory and recognizing some resolutions of the Cabinet of Ministers of Ukraine as invalid) Постанова Кабінету Міністрів України від 05 червня 2019 р. № 476. Viewed 21 January, 2021, (https://zakon.rada.gov.ua/laws/show/476-2019-\%D0\%BF). (in Ukrainian) 


\section{Information about authors:}

Iryna Koshkalda, Doctor of Economic Sciences, Professor, Chair of the Department of Land Resources Management and Cadastre, Kharkiv National Agrarian University named after V.V. Dokuchayev. Dokuchaevske-2, Kharkiv district, Kharkiv region, 62483, Ukraine, +38 05032355 94, irinavit1506@ gmail.com. Land managenet, rational land use, land evaluation, land cadastre.

Tetiana Anopriienko, Candidate of Economic Sciences, Associate Professor of the Department of Planning of the Territory of Settlements and Construction, Kharkiv National Agrarian University named after V.V. Dokuchayev. Dokuchaevske-2, Kharkiv district, Kharkiv region, 62483, Ukraine, +38 0956888377 , atatyanav2017@gmail.com. Land managenet, rational land use, land evaluation, land cadastre, planning of territory.

Maryna Pilicheva, Candidate of Technical Sciences, Associate Professor, Associate Professor of the Department of Land Administration and Geoinformation Systems, O. M. Beketov National University of Urban Economy in Kharkiv, 17, Marshala Bazhanova Street, Kharkiv, 61112, Ukraine, +38 0992125804 , maryna.pilicheva@gmail.com. Land managenet, rational land use, land cadastre, geodesy, remote sensing.

Lubov Maslii, Senior Lecturer of the Department of Land Administration and Geoinformation Systems, O. M. Beketov National University of Urban Economy in Kharkiv, 17, Marshala Bazhanova Street, Kharkiv, 61112, Ukraine, +38 09917848 80, gnomomir@gmail.com. Land managenet, rational land use, land cadastre, geodesy. 